\title{
Genderové aspekty displacementu
}

\author{
Gerlinda Šmausová
}

\section{1. Úvod}

Podle textů rámujících workshop „Displacement/Vymístěni““ je možno slovo „displacement" chápat v českém významovém kontextu jako vyhnání, vysídlení, odsun. Po úvaze o možných formách odcizení domova nebo odcizení se domovu navrhují autoři těchto textů zavedení českého pojmu „vymístění“. Vymíst’ováni jsou nejen ti, kteří nuceně změnili časoprostorovou koordinátu sociálního prostoru, do kterého se narodili, ale i ti, jejichž prostor je kolonizován, at' prostřednictvím fyzického či symbolického násilí. Po úvaze o všech možných jevech zasluhujících si smutné, protože „dis-sociační“ předpony „dis“, není důvodu, nezahrnout mezi ně i procesy, dosud popisované jako migrace. Podle názoru významných autorů ${ }^{1}$ migrace $\mathrm{v}$ historii jen málokdy nebyly provázeny útlakem, bídou, násilím a válkou. ${ }^{2} \mathrm{O}$ tom svědčí již samotný fakt, že migrační vlny vznikají v místech, která mají nedostatečnou subsistenční úroveň nebo jsou proměněna ve válečná pole, a pohybují se k místům s výhodnějšími možnostmi reprodukce, pokud možno za mírových podmínek.

V literatuře byl relativně dlouho přehlížen genderový aspekt, který znamená více než pouhou deskripci faktu, že migrací jsou postiženi muži i ženy. Jde spíše o to, že zdánlivě stejné procesy mají pro obě gender zpravidla velmi odlišný význam.

Literatura ke genderovému aspektu vymístění dosud není samostatně systemizována, takže první krok $\mathrm{k}$ podpoření nového směru výzkumu bude spočívat alespoň v částečném zmapování dosavadních příspěvků. Rýsuje se několik oblastí, ze kterých je možné jako z primárních pramenů čerpat anebo které již výsledky výzkumu obsahují: Genderový aspekt migrací se objevuje v dokumentaci historické paměti žen, v jejich vyprávěních a denících. Ty pojednávají jak o praxi provdávání se za muže stejných i jiných národností v imigračních zemích, tak o podvodných praktikách vylákávání žen za účelem jejich přinucení k prostituci (kapitola 2). Dalším aspektem, který se v denících žen pojednává, je znásilňování žen jako příčina vymíst’ování. V literatuře povětšinou zpravodajského charakteru, ale i v právní dokumentaci, se pojednává násilí vưči ženám jako strukturní podmínka života v určitých zemích, což se stává uznávaným důvodem pro přidělování politického asylu (kapitola 3). V průběhu vysídlovacích procesů, tak jak to bylo zaznamenáno ve zmíněných denících, se pak zjevuje jádro genderové struktury, a sice heterosexuální přitažlivost. Možnost směňování tělesných služeb ze strany žen za zlepšování podmínek vysídlování odhaluje, že sexualita může působit jako subverzívní síla, která narušuje oficiální struktury (kapitola 4). Od této dokumentace, která zachycuje ženy jako komoditu nebo dar, jako oběti násilí či směňovatelky ,poslední, sexuální ressource“, se odlišují optimistické zprávy o ženách, pro které displacement znamenal osvobození od různých forem genderové nesvobody ve staré a nový začátek v nové vlasti (kapitola 5).

Sociálni studia. Fakulta sociálních studií Masarykovy univerzity v Brně, 2/2004. S. 9-26. ISSN 1214-813X. 
Tento výběr témat vyplynul z procesu hledání genderových aspektů vymíst'ování, a je proto na míle vzdálen systematickému pojednání. Ve stati uvedeme příklady pocházející z různých pramenů i př́stupů a naznačíme jejich teoretickou relevanci z analytického pohledu genderu. Ad hoc, po komentáři Mgr. Tomáška, docházíme k poznání, že genderový aspekt vymístění hlavně obohacuje genderovou teorii samu (kapitola 6).

\section{2. Ženy provdané a ženy prodané}

\section{1. Ženy provdané}

Již samotný princip patrilokality měl v mnoha zemích za následek, že žena po provdání opustila své rodiče a sourozence, své příbuzné a přátele, svou rodnou ves, a přestěhovala se do domácnosti svého manžela (Hoerder 1993: 12). Tato tzv. mikromobilita bývá často přehlížena, i když pro vymístění jako proces ztráty či vzdání se důvěrného a nutnosti akulturace v novém prostředí není důležitá vzdálenost v kilometrech, ale rozdílnost kultur. Kulturní rozdíly byly v segmentárních společnostech partikulárních kultur daleko větší než dnes, takže vymístění z jedné vesnice do druhé znamenalo přestěhování se „daleko, třeba až k moravským hranicím“, abychom parafrázovali Jeníka z Prodané nevěsty.

Podle Hoerdera vedla pozornost věnovaná genderovým aspektům k diferenciaci migrace na mikro a makro, a dále na migraci z produktivních důvodů, která se přisuzuje mužům, a migraci z důvodů reproduktivních, která se týká převážně žen. Migrace mužů k místům s možností produkce bývá častější, migrace žen za účelem reprodukce méně častá (tamtéž: 12). Hoerder se zabývá jen migrací, která byla účastníky jakoby sama zvolena, a proto se ve schématu, které nabízí, nevyskytuje vlna vymístění související s druhou světovou válkou, kterou zdůrazňuje Bammer (1994: xi).

Podle Hoerdera mají migrační procesy, at’ vnitrokontinentální evropské či mezikontinentální, směřující z Evropy do Asie (sibiřský prostor), do Severní i Jižní Ameriky, do Austrálie a Oceánie, po staletí stejné schéma.

$\mathrm{Z}$ různých důvodů klesá výnos z parcelované nebo již neúrodné půdy ${ }^{3}$ pod subsistenční úroveň, což vede muže k tomu, aby se vydali ,za chlebem nebo za prací“, dobývat a obdělávat novu půdu, nebo později hledat práci v nově vznikajících průmyslových centrech. Ženy zase zjišt'ují, že výrobky jejich rukodělné domácké práce se staly příliš drahými, a proto neprodejnými, ve srovnání s průmyslovými produkty. ${ }^{4}$ Proto např́klad v letech 1820-30 došlo ke značné krátkodistanční migraci žen z domácností do textilních továren. Migrační distance žen se ale neúměrně zvětšuje, když rodinná strategie jako zprostředkovatel mezi tzv. objektivními podmínkami a subjektivními motivacemi rozhodne o postupné migraci celé rodiny.

Takovýto typ migrace popsala ve svém deníku Rosa, žena z italského venkova, která emigrovala do Spojených států. ${ }^{5}$ Rosa byla schovanka rodiny žijící v extrémně chudé vesnici nedaleko Milána. ${ }^{6}$ Jako sedmiletá byla stejně jako její vrstevnice dána na práci v továrně na zpracování hedvábí v jiné vesnici, což byl př́ipad obvyklé krátkodistanční migrace dívek před svatbou. Chlapci ve věku kolem deseti let byli posíláni na práci až do Francie (střední distance), starší ženatí i svobodní muži se vydávali za prací až za oceán (velká distance). 
Někteří ženatí muži brali své ženy s sebou hned, „nebot’ bylo třeba někoho, kdo by jim vařil, pral a zašíval“" (Hoerder 1993: 26). Některé ženy své muže následovaly po roce a více. Rosa byla ještě v Itálii provdána za jí předtím neznámého muže, ${ }^{7}$ který brzy odešel do Missouri. Po několika letech vyzval Rosu, aby za ním přijela - ale bez jejich společného syna, kterého musela nechat u svých př́buzných. Rosa se přes oceán vypravila se skupinou, která reprezentovala tehdy možné typy emigrace: Byli v ní rolníci, kteří dosud nikdy neopustili rodnou ves, ženy s dětmi, které se po letech (nuceného) odloučení konečně mohly vypravit za manžely, žena, která se měla v Americe vdát za krajana, kterého nikdy předtím neviděla. ${ }^{8}$ Pro ženy manželství predstavovalo vstupenku do Nového světa; dřívější reproduktivní (patrilokální) migraci z jedné vesnice do druhé nahradila migrace na vzdálenost tisíce kilometrů.

Druhý den po prŕijezdu a slavnostním přivítání se Rosa chopila práce, kterou již vždy vykonávala: vařila pro dvanáct mužů-horníků, mezi nimiž byl i její manžel, jídla, na jaká byla zvyklá v rodné vsi, a z genderového hleidiska se chovala tak, jak byla zvyklá ona i oněch dvanáct mužů. Migranti tohoto druhu bezprostředně navazovali na svou výchozí kulturu, přičemž ke změnám docházelo teprve v průběhu času. Podle Rosina vyprávění se chudí a nevzdělaní italští muži přestali chovat výhradně submisivně nejen k nadřízeným, ale ke všem lidem s bílými límečky, ženy se navíc začaly vymaňovat i z područí svých manželů. Rosa si například začala ukládat malou částku peněz, o kterých manžel nevěděl. Když po několika letech navštívila rodnou ves, aby tam vyzvedla svého syna, viděla ji již očima Američanky, která si je vědoma privilegií, kterých se jí - přes všechnu přetrvávající relativní chudobu - v Americe dostává. Reemigrace pro ni nepřichází v úvahu; naopak, po návratu do Ameriky se osvobozuje i od svého násilného manžela.

Rosino story má happy end - Rosa se přistěhovala sice do Ameriky, přitom ale do italské vesnice, s mírně ,unifikovanou“ krajovou venkovskou kulturou, kde se přizpůsobení (akulturace) týkalo především politické kultury. Přesto se jedná o vyprávění o těžkém životě plném chudoby, příkoří, nátlaků, které vedly napřed Rosiny rodiče a později ji samu k přesvědčení, že opuštění rodného kraje, její kvazi-dobrovolné vymístění, je tou lepší volbou. Rosa byla také ochotná plnit své reproduktivní funkce, ale jak bylo naznačeno, jednalo se ani ne tak o péči o děti (syna musela zanechat ve ,staré vlasti“), jako o péči o manžela, přesněji řečeno o reprodukci mužské pracovní schopnosti.

\section{2. Ženy prodané}

Tragický osud očekával ženy, které se vydaly za pouhým přeludem manželství a které místo toho skončily jako prostitutky. Shodou okolností je nám přístupný příběh ženy ze stejné doby, tj. z poloviny 19. století, a sice ve formě dopisů, tajně psaných z bombajského nevěstince. ${ }^{9}$ Ženy unešené z Podkarpatské Ukrajiny prosí v dopisech rakouské úřady, aby zarazily kriminální aktivitu zběhlého vojáka, obchodníka bílým masem a pasáka Morize Bergmana. Tento muž odlákal mnoho mladých žen i nedospělých dívek pod záminkou uzavření manželství z jejich rodin a rodných vsí, aby je doslova prodal na trhu sexuálních služeb.

Historička A. Staudacher(ová) popisuje životní podmínky v místech, odkud tyto ženy pocházely: v haličských židovských, „štetlech“. Pro bídu a hlad, které tam vládly, Poláci Halič přezdívali „Glodomeria“, což česky znamená něco jako hladomorna. ${ }^{10} \mathrm{Na}$ velmi omezené 
ploše zemědělské půdy bylo tě̌̌ké vyprodukovat dostatek potravin; ševcovství a krejčovství neneslo výdělky, které by stačily k výživě početných rodin. Židovská tradice vyžadovala, aby dívky do manželství přinesly dostatečné věno - a tak stejnou měrou, jakou začali přebývat mladí muži bez výdělku, začaly přebývat mladé ženy, kterým rodiče nemohli poskytnout věno. Proto se i ve štetlech, stejně jako v Itálii, mnoho jedinců rozhodlo pro emigraci - muži, staří i mladí, tedy otcové, bratři a potenciální ženiši, odcházeli převážně na západ, až do Ameriky, čímž se přebytek mladých, manželství schopných žen, nicméně „hladových krkü“, jen ještě zvýšil. Matky byly nuceny převzít ženskou i mužskou zodpovědnost za život zbylých členů rodiny. Této situace využívali podvodníci, často stejného židovského původu, k odlákání dívek, kterým velkoryse „odpouštěli“, že nemají věno (kdo by si nevzpomněl na novelu „Tovje vdává dcery“?). Dívky z Haliče byly prodávány do Indie, Argentiny, někdy „,jen“ do Vídně, jindy do o něco vzdálenějšího Hamburku. ${ }^{11}$ Jen z Haliče ročně zmizelo kolem tisíce dívek, které měly zpravila jen krátký život - pokud byly prodány ve věku 17 nebo 18 let, pak umíraly dvaceti- až dvacetipětileté na venerické nebo jiné choroby (Staudacher 1996: 14).

Policii byly známy všechny triky, kterými obchodníci s lidmi ${ }^{12}$ dívky napřed odlákali, sebrali jim správné pasy a vybavili je falešnými, jak je dodávali bud’to do „sweat shopư“ nebo rovnou do nevěstinců, barů nebo jednotlivým pasákům. Již tehdy ale existoval organizovaný obchod s bílým masem, přičemž „organizovaný“ zde znamená, že jsou do něj zapojeny právě ty orgány, které by měly proti tomuto typu otrokářství bojovat.

Z beletrie je známo, že bordely existovaly i prímo v místech, ze kterých byly dívky unášeny. Jejich zákazníky byli hlavně rakouští úředníci či př́slušníci C. a K. armády. K tomuto jevu bychom se nutně propracovali při sledování kořenů dnešního „sexturismu“, totiž faktu, že občané bohatých národů jezdí upokojovat své pohlavní a jiné regresivní tužby do zemí třetího světa nebo obecně do míst, kde vládne nedostatek. Vymístění žen prostřednictvím mobility „koloniálních“ pánů má stejně dlouhou historii jako násilná mobilita žen.

Připomeňme si tuto tradici jak násilného vymístování, dnešního „trafficking“, žen, ${ }^{13}$ které během svého většinou krátkého života ani nemají možnost kompenzovat ztrátu svého přirozeného prostředí výhodami míst, do kterých byly přivlečeny, tak žen, které jejich prostředí vymístilo samo.

Položme si ale také otázku, co v tomto př́padě znamená označení „reproduktivni““ migrace - u prostituce se už vůbec nejedná o rození a výchovu dětí, ani o reprodukci pracovní síly mužů, ale o nucené poskytování sexuálních služeb mužům, kteří za ně jednorázově platí.

\section{3. Ženy jako dar, ženy jako komodita}

Připust'me, že migrace za prací a chlebem, která je vynucená tvrdými životními podmínkami, je i pro muže často spojena s tím, že i v nové zemi mu bude odepřen plnohodnotný status, úplný př́istup $\mathrm{k}$ povinnostem a právům. Zdá se ale, že ženy jsou $\mathrm{v}$ tomto pořadníku na společenský status zařazeny až za muže, protože jednou z podmínek jejich emigrace je manželská smlouva s individuálním mužem. Tato smlouva oba manžely explicitně zavazuje $\mathrm{k}$ vzájemné věrnosti a podpoře $\mathrm{v}$ dobrých i zlých dobách, dokud je nerozloučí smrt. Že muž i žena budou mít jak rozdílné funkce - muž bude živitelem rodiny a žena „,v domácnosti“ -, tak rozdílnou moc, - pán bude „pánem“ a žena „rabem“-, se ve smlouvách jen implicitně, 
podle nepsaného zákona, předpokládá. Muž na veřejném pracovním trhu směňuje za plat svou pracovní sílu a ne celé své tělo, ${ }^{14}$ a proto si zachovává svobodu pohybu. Žena v manželské smlouvě směňuje své tělo a s ním i svou svobodu, protože nemůže z místa, kde získává živobytí, odejít. Jakkoliv ale tato smlouva reprodukuje nadřazenost mužů, vyhrazuje ženám právo na zajištění subsistence, a jak se má za to, i na ochranu. Za pojmem reprodukční funkce se ovšem neskrývá, jak by bylo možné očekávat, v prvé řadě rození a výchova dětí, ale reprodukce mužů samotných - vaření, praní, ošetřování v nemoci, hlavně ale uspokojování sexuálních a jiných regresivních tužeb manželů.

V posledních dvou bodech se práce vdaných žen překrývá s prací žen prodaných. Ty ale nejsou chráněny ani manželskou či vůbec nějakou smlouvou, jejich postavení je právem označováno za novou formu otroctví. Záleží jen na jejich vlastníkovi, jestli bude se svou komoditou „sexuální pracovnice“ zacházet šetrně, anebo ji bude vykořistovat, až k rychlému úplnému fyzickému vyčerpání. Dokud existuje bída, je pro novodobé otrokáře relativně snadné pořizovat si na „trhu s bílým masem“ jiná ženská těla.

Migrující ženy provdané i prodané sdílí osud, který byl obecně ženám připsán v tzv. sexuálni smlouvě. Podle Pateman(ové) (1988) muži-bratři mezi sebou uzavřeli sexuální smlouvu o tom, že jen mužům bude přidělena individuální svoboda a že jen oni se stanou vlastniky své vlastní osoby, svého vlastního těla. Proto ženy zůstávají i v moderní době prostředkem, který si mezi sebou vyměňují muži. $V$ př́znivém př́padě se jedná o výměnu mezi muži príbuzných sociálních vrstev a kohort, což jen $\mathrm{v}$ jiné formě opakuje předhistorickou praxi předávání vlastních dcer a sester jako „daru“ mužům jiných kmenů, tak jak to popsal Lévi Strauss (2000). Tyto ženy - dcery a sestry - jsou chráněny manželskou smlouvou, na jejíž dodržování dnes dbají otcové i bratři ve funkci veřejných zákonodárců a soudců. Stejní historičtí muži, které má na mysli Patemanová, ale zřejmě uzavřeli i nepsanou dohodu o tom, že část žen bude z prŕíbuzenských svazků vůbec exkludována a považována za volně príistupnou komoditu. Ale nezávisle na tom, zda jsou ženy darem nebo komoditou, společné je jim to, že se jim de facto nepřiznává vlastní subjektivita. Moderní subjekt je mužského rodu, jen muži vstoupili do moderní společnosti, zatímco ženy zůstávají v př́rodním stavu mnohoznačných determinací.

Tento nesvobodný stav se neprojevuje nikde tak jasně, jako právě $v$ současných procesech vymístování žen. Vztahuje se například jak na filipinské brides, které opouštějí zemi se slibem manželství, tak na dívky z „východních zemí“, které se vydávají na západ jako potenciální „slečny k dětem“, aby skončily jako ilegální prostitutky.

\section{Znásilňování žen jako příčina vymístování}

\section{1. Znásilňování žen jako součást strukturního násilí}

Prameny popisující znásilňování žen často nalézáme v právnické literatuře, která se zabývá otázkou, zda se jedná o dostatečný důvod pro přidělení politického azylu ženám (Laubenthal 1999). Jako znásilnění se označuje vynucený orální, anální a vaginální pohlavní styk. Někteří autoři ztotožňují znásilnění s tělesným týráním, které je u mužůu uznáváno za 
platné zdůvodnění žádosti o azyl. Znásilňování žen se v azylovém řízení nepovažuje za jednorázový kriminální počin jednotlivého muže, ale za násilný strukturní prostředek udržování mužské nadvlády nad ženami v určitých zemích. ${ }^{15}$ Praxe znásilňování žen je zvláště rozšiřrena tam, kde je dosud tradiční nadvláda mužů ohrožena mírovým „moderním“ hnutím za zrovnoprávnění žen, anebo tam, kde je nadvláda jedněch mužů ohrožena ,jinými““ muži, což je príznačné pro války a tzv. etnické čistky.

Je důležité si uvědomit, že sexualita není motivem ani cílem, ale nástrojem násilí. Pachatelům nejde o uspokojení sexuálních potřeb, ale o úplné ponížení své oběti až ke ztrátě osobnosti. Vedle těžkých fyzických zranění vede násilná penetrace těla ke ztrátě vnitřní sebeidentity, k „mortifikaci“ Já. Protože se násilí mužů vůči ženám vyskytuje ve všech společnostech, mohlo by se zdát, že je zbytečné, aby ženy opouštěly svou vlast a hledaly ochranu v jiných, zpravidla západních zemích. Právnická literatura ale zdůrazňuje, že společnosti, které se zavázaly k dodržování charty Lidských práv, na rozdíl od zemí, kde je násilí trpěno, zaujímají ke znásilnění žen kdekoliv na světě rozhodné odmítavé postoje. A tak se při udělování azylu zkoumá, zda v ženině vlasti znásilnění tvoří součást státního represivního aparátu, jestli je znásilnění vůbec považováno za trestný čin a zda jsou pachatelé tolerováni nebo stíháni.

Laubenthalová jako př́iklad státní tolerance znásilnění uvádí Pákistán, kde se vojenská vláda pod velením generála Zia v roce 1979 pokusila „reislamizovat“ zákony a soudnictví. Podle nového zákona musí znásilnění být před soudem prokázáno čtyřmi mužskými muslimskými očitými svědky. Prakticky ale nepřichází v úvahu, aby se našli čtyři muži, kteří by svědčili proti pátému, který je členem jejich vlastní skupiny. Zvláště prekérní se pro svobodné ženy stává situace, kdy po znásilnění otěhotněly: pokud znásilnění zmíněným způsobem neprokáží, mohou být za mimomanželské početí potrestány zbičováním a odsouzeny až $\mathrm{k} 10$ letému věznění. Znám je př́pad znásilněné třináctileté dívky, která byla zbičována a odsouzena $\mathrm{k}$ tříletému trestu. Dítě porodila ve věznici. Spojení skutkové podstaty znásilnění s mimomanželským sexuálním stykem nejen že ženy nechrání, ale vystavuje je nebezpečí manipulace ze strany rodičůu, rodiči domluvených snoubenců a jiných zájemců o ženiny schopnosti (1999: 27 a dále).

V jiných zemích, např́íklad v Erytrei, je sice znásilnění definováno jako trestný čin, ale veřejné mínění je tak zaujato proti obětem, že je prakticky připraví o dosavadní status a plánované životní trajektorie. Dívkám, které znásilněním přišly o panenství, zbývají než tři nesvobodné volby: provdat se za pachatele - pokud je k tomu ochoten -, vzít si o hodně staršího muže, nebo starat se o vdovce s mnoha dětmi. V Indii stigmatizace obětí dř́ve vedla až k usmrcení žen, dnes vede $\mathrm{k}$ jejich exkluzi z rodinného svazku. Po znásilnění a vyloučení z rodiny jim zbývá jen práce prostitutky - podle odhadů je $80 \%$ indických prostitutek obětí znásilnění. ${ }^{16}$

Kromě takovýchto „spojenectvi““ státních činitelů s pachateli násilných činů vůči ženám existují důkazy o jejich př́mé účasti na násilí. Organizaci Amnesty International jsou známy př́pady z Guyany, opět Indie a Pákistánu. V Maroku existuje ,alarmující záznam dosvědčující systematické znásilňování a napadání bezpečnostními silami“ (Laubenthal 1999: 33, podle Krell a Wölte 1995). Obzvlášt' ohrožené jsou př́slušnice minorit (v evropských zemích například Roma a Sinti). V Rumunsku se při vyhánění romské populace z vesnic podíleli rumunští muži společně s př́slušníky policie na znásilňování romských žen, aniž by kdy došlo k jejich trestnímu stíhání. 
V Mauretánii, Etiopii, Argentině, Peru a dalších zemích patří znásilňování, „braní si“ žen, k nepsaným právům vojenských posádek, zvláště pak okupačních. Nezř́́dka se stává (například v zemích bývalé Jugoslávie, že vrchní velitelství trpí násilné donucování žen k prostituci s př́slušníky posádek, které mají zajišt'ovat ochranu obyvatelstva, k němuž ženy patř́i.

Ve vnitrostátních konfliktech patří znásilňování žen $\mathrm{k}$ běžným „zákrokům“ policie a vojska proti politickým, národnostním či etnickým odpůrcům. Tisk a zprávy mezinárodních komisí uvádějí prípady z Kosova, ze Zaire, z Haiti, Guatemaly a mnoha dalších zemí. Laubenthalová cituje tento př́ípad ze Srí Lanky: „Na protivládně politicky činného tamilského muže byl vydán zatykač. Muž nevyčkal př́íchod vojska a skryl se v ilegalitě. Doma zůstala jen jeho žena, $v$ třetím měsíci těhotenství. Tři vojáci, kteří měli muže přivést, znásilňovali ženu tak dlouho, až potratila." ${ }^{\prime 17}$

Znásilňování se stalo pravidelnou součástí týrání např́íklad ve vězeních Chile, v San Salvadoru a v Turecku:

V prvních týdnech zajetí se musela Guenay Korkut mnohokráte svléknout, načež byla pověšena za provazy upevněnými na zápěstí. Týrali ji elektrickými šoky, které uplatňovaly i na genitálie a na prsa. Obtěžovali ji sexuálně... Guenay Korkut omdlela. Když se probudila, tekla jí po stehnech krev. Už není pannou, poznamenal jeden strážce cynicky... ${ }^{18}$

Tyto stručné informace o znásilňování žen představují sekundární výběr případů z publikace Laubenthalové, která se pokusila o systematický přehled právně relevantních situací, které zdůvodňují žádost žen o politický asyl. Autorka sice nevylučuje znásilňování mužů jinými muži v podobných situacích, zřejmě právem se ale domnívá, že nejčastěji jsou znásilňovány ženy. Přitom je znásilňování formou displacementu pro ženy se št’astnějším osudem. Nešt’astné ženy zůstávají k místu jejich ponižování a ohrožování na životě připoutány. Laubenthalová se zmiňuje o těch štastnějších, nebot' jejich př́ípady vešly ve známost $\mathrm{v}$ souvislosti s podařeným útěkem a žádostí o politický azyl.

\subsection{Znásilňování jako engendering displacementu a embodiment etnika, národa, politické strany}

Znásilnění samo není důvodem pro žádost o azyl a jeho udělení, jsou to spíše politické poměry, za kterých je znásilňování žen rozhodujícími orgány trpěno nebo dokonce schvalováno. Znásilnění tak mají, kromě kvantitativního kriminalistického rozměru, který „sčítá“ individuální násilné činy ze strany mužů a individuální utrpení žen, také rozměr kvalitativní. Jak již bylo zmíněno, považuje se znásilňování za strukturní násilí, kterému jsou individua lhostejná, protože se na nich ,jen“ uskutečňuje určitý skupinový záměr. Mưže se jednat o záměry politických, národnostních či etnických, náboženských nebo jen „mužských“ seskupení, které na svých obětech demonstrují vlastní převahu. Ve všech těchto konstelacích muži prostřednictvím násilné uzurpace ženských těl „odcizuji““ protivníkovo „tělo“ (body, Körper) a přeměňují ho na tělo „mateřské“ strany, „matičky“ vlasti, „rodného“ etnika či národa, „matky“ církve atd.

Na schopnost ženského těla „ztělesňovat“, tzn. symbolizovat integrované celky (srovnej pojetí ,,společenského organismu“ u Spencera a Durkheima), upozornila ve své a objevné a záslužné práci Dubravka Zarkov: 
Tělo žen sloužilo k vyslání signálu, poselství, nepř́iteli, jak k tomu nacházejícímu se uvnitř, tak vně vlastní skupiny. Schopnosti a vlastnosti ženského těla se staly významnými prvky násilného jednání stejně jako rétoriky odlišných bojujících stran... Ženské tělo je ze své podstaty dvojznačnou kategorií... ženské tělo má jedinečný potenciál reprezentace.

(Zarkov 1999: 34 a dále)

Hlavním důvodem dvojakého významu ženského těla je jeho skutečná vlastnost: rozením udržovat a rozmnožovat tu kterou zájmovou skupinu. Patriarchální řád proto považuje za nutné neustále kontrolovat ženskou sexualitu a prokreativitu. Zmocněním se a předpokládaným oplodněním soupeřových žen je položen základ k soupeřovu úpadku. Politické př́slušenství, mezi které Zarkov zahrnuje i etnickou př́slušnost, ${ }^{19}$ má svoji „tělesnou“ stránku a teoretická pozornost věnovaná násilným ekcesům vůči ženám - engendering ethnicity - odhaluje, že se jedná o dosud přehlížený významný prostředek konstrukce národa, etnika apod. Podrobování si žen znamená symbolicky-nesymbolickou produkci etnika, tzv. embodiment of ethnicity (Zarkov 1999: 54 a dále). ${ }^{20}$

\section{Násilí a sexuální směny během odsunu či útěku}

\section{1. Znásilňování žen}

Ženy v odsunu či ženy na útěku před násilím nemají ani zdaleka vyhráno. Během jejich různých anabází jsou nejen vystavovány vysokému riziku znásilnění, ale zpravidla i neustálému víceméně represivnímu nátlaku směňovat „tělo“ za ochranu, různé služby, ulehčení těžké situace, za léky, potraviny atd. Tato zvláštní genderová situace žen při vymíst'ování je nesčetněkrát zdokumentovaná v literatuře o poválečném odsunu Němců. Abychom vyprávění o situaci žen př́lišs nezatěžovali ožehavým národnostním problémem, vybrali jsme deník Margarety Schellové, mladé herečky německého původu, která od svého narození žila a působila v Praze. V květnu 1945 byla zadržena a spolu s jinými ženami odvedena ke stavění barikád. Do svého bytu se již nesměla vrátit. Po úspěšném povstání byla internována v různých pracovních táborech, kde téměř po roce dostala př́kaz k vysídlení. Deník Schellové není prostý výrazů a názorů, které bychom dnes označili za politicky nekorektní - např́klad netečnost k právě ukončené válce a jejím prríčinám, k důsledkům pro Československo nebo časté poukazování na národnost či rasu, ${ }^{21}$ soustřed’uje se ale hlavně na líčení každodenních trampot, na nemožnost se umýt, hlad, tvrdé podmínky pracovního nasazení, zimu a nemoci, čímž bezděčně odhaluje všudypř́itomný genderový aspekt vymíst'ování.

Jako červená nit se deníkem prolíná strach z Rusů, které předchází zlá pověst, že znásilňují ženy. Mezi Rusy a uvězněnými německými ženami se ale nachází české stráže, které podle Schellové ženy spíše chrání, než aby je vydávaly napospas osvoboditelům:

10. května: V noci najednou slyšíme křik stráže, těžké kroky, pak náhlé ticho. U nás ještě jednou rozsvítili, jeden ze strážců vstoupil a řekl česky: Bud’te úplně klidné, schovejte se pod dekami, jsou zde Rusové. Světlo hned zase zhaslo. Rita a já se třeseme po celém těle, netroufáme si ani šeptat. Nikdy jsem nevěrila zprávám o ohavných činech Rusů a jejich neustálém znásilňování žen, které šířila německá propaganda, rozhodně ne v jejich rozsah. Ted' mi ale srdce tluče až k puknutí. Je to pro nás cizí národ, o kterém málo víme. Rusové! Ted' nás to neznámé naplňuje děsem. [...] Z velikého sálu odvedli čtyři dívky a slíbili je za dvě hodiny vrátit. [...] 11. května v 8 hodin ráno se dívky objevi- 
ly, úplně vyřízené. Hned si lehly. Všechny byly znásilněny. To slyším od ostatních, které byly tak netaktní, se jich zeptat, jaké to bylo.

(Schell 1957: 19-20)

Tyto hrozby znásilnění se přes intervence českých stráží udržují až do konce roku, zmínky o nich se v deníku mnohokráte opakují, např́klad s touto, z kriminologického hlediska neinformovanou, ageistickou nuancí:

16. květen: Nejvíce strachu mají staré ženy, čímž i v tomto napjatém okamžiku působí komicky. Stahují si šátky hluboko do obličeje, svazují ho pod bradou, dělají se staršími. Přes bušení srdce, které se hned dostavuje, se musím usmívat. Věrím, že na těch by se i bez přestrojení neprohřešili ani Rusové. [...] Vzpomínám, jak jsem tehdy litovala ty čtyři dívky, a jak jsem byla zaskočená, když jedna z nich vyprávěla, jak dobře se bavila, jak milý k ní byl, jak dobře se najedla, a že samozřejmě došlo k nevyhnutelnému. Ale byl prý k ní velmi milý. Ani ty ostatní to, jak se zdá, neberou př́iliš tragicky. Jak smutné vysvědčení pro nás ženy.

(Tamtéž: 27)

Stav permanentního ohrožení žen na útěku je obdobnou formou svrchu diskutovaného strukturního násilí, jehož latentní funkcí je embodiment poroby poraženého národa.

\section{2. Sexualita jako směna, „poslední ressource"}

Poslední příklad ale také naznačuje přechod od vynucené sexuální služby ke směně quid pro quo, stejně jako tento záznam:

27. května: Světlovlasá Češka, rozená Vídeňačka - jsou tu internováni i mnozí Německu naklonění Češi, tzv. „kolaboranti““ - si získává různé malé výhody tím, že se oddává staršímu policistovi, který má na naší chodbě službu každý druhý den. Slibuje si od toho dřívější propuštění a dostává od něj i občas něco k snědku. A já hladovím! Potravinovým lístkům, které ještě někteří měli, dochází platnost, nic se již nedá pořídit, nikdo již nic nevydá ze svých zásob.

(Tamtéž: 40)

Autorka sama se z takovýchto obchodů vyjímá, jí samé se dostává přízně na základě jejích osobních vlastností, je koneckonců ještě mladá herečka (i když mezi vězněnými ne nejmladší žena):

21. května: Včera se kapitán ke mně, své kinohvězdě, [česky v německém originále], jak mě oslovuje, choval ještě žoviálněji. Chtěl se mnou a několika děvčaty a strážci pít víno v nyní již vyklizeném velkém sálu. Bylo mi to velmi nepř́ijemné. Př́ímo odmítnout jsem nemohla; jsme přece zcela závislé na těchto lidech a briskní odmítnutí by pro mě mohlo mít závažné následky. Na druhé straně jsem si samozřejmě řekla, že tento večer určitě neproběhne nevinně. Děvčata hned nadšeně souhlasila, beztoho často seděla celé večery na chodbě, aby se mohla bavit se strážci, a později, po zhasnutí světel, se jim vtírat, jen aby pro sebe získala výhody. Já ale koneckonců mohu včas zmizet.

(Tamtéž: 32) 
20. srpna: Náš velitel [česky v něm.originále] mi rychle řekl, když jsem ho míjela, že nemám mít strach, že se jedná o férovou záležitost, že budeme v 10 večer zpět a že budeme na letišti jen loupat brambory. Nastoupila jsem tedy s ostatními pěti ženami do otevřeného vozu, kde již seděli dva Rusové. Jeden z nich mi hned nabídl cigaretu a jízda v otevřeném voze byla nádherná. Ale když jsme letiště míjeli, jalo mě podezření. [...] Zavedli nás ke stolům, na brambory prý dojde později. Sotva jsme si sedly, objevili se další Rusové, kteří přinesli maso, koláče a vodku a vyzvali nás k jídlu a pití. Ted' jsme věděli, kolik udeřilo, ale zůstala jsem docela klidná s myšlenkou, že se nějak dostanu i z této situace. [...] Některé z dívek se podnapily a chovaly se vyzývavě, nekladly odpor. [...] Můj společník mě vyzval k odchodu do vedlejšího pokoje, abychom nebyli rušeni. Bránila jsem se, ale uklidňoval mě, a dal mi čestné slovo, že mi neublíží [...] slovo dodržel. [...] Mezitím se spustila bouřka a průtrž mračen; dívala jsem z okna a přemýšlela, jak se odsud dostat. Už muselo být dávno po desáté. Rus mě pohladil po vlasech a zašeptal: Marguerito!

(Tamtéž: 110)

V těchto a jiných př́hodách se objevují muži jako rytíři i vưči poraženým ženám a autorka sama vystupuje jako vyvolená dáma. Vedle svého mládí často zdůrazňuje svoji kultivovanost, pro kterou jí dávají přednost stejně kultivovaní muži z vítězného tábora. Chovají se k ní jako gentlemani, nenutí ji k sexuálnímu aktu. V analytickém jazyku sociologie to znamená, že kulturní kapitál převyšuje vliv genderové příslušnosti, pokud ovšem potenciální násilník na známky kultivace bere ohled! Jestli Margareta Schellová ve svém deníku nic nezatajuje (v každém prrípadě se líčí v př́iznivějším světle než ona „děvčata“), dokázala svůj kulturní kapitál v boji o svou duševní a tělesnou integritu využít. Její př́ípad bychom mohli označit jako směnu kultivované ženskosti.

Gender je rovněž směnitelný za právní status, jak naznačuje následující krátký př́íklad:

26. srpna: Zase - zaplat’pánbůh - klidná neděle. Dokonce došlo k jednomu propuštění. Ale ženich této dívky je Čech. J e d n o propuštění, enormně mnoho při téměř tisíci lidí!

(Tamtéž: 116.)

Deník se o takovýchto mezaliancích mezi vítěznými a poraženými zmiňuje častěji. Směny podobného druhu by bylo možné doplnit nesčetnými př́ípady ze současného globálního sňatkového trhu. Pravé či fingované sňatky mužů s výhodným statusem se ženami, které nemají nic než své tělo, které jsou ochotny směnit za živobytí, jsou rozšśřrenou praxí. ${ }^{22}$

\section{3. Heterosexuální konstelace}

A kdyby se nejednalo o směnu ženské lásky za vynětí z odsunu přes sňatek s Čechem, byla by to již samotná heterosexuální konstelace, která ovlivňuje vztah mezi muži-strážci a internovanými ženami. V celém deníku je bezděčně zachycena skutečnost, že dozorci a vězeňkyně se vnímají jako př́slušníci rozdílného pohlaví. Některé poznámky sice spíše vyjadřují nezištnou, humánní pomoc, ale ani z nich nelze přítomnost genderu odmyslet:

31. května: Večer má službu pan Válek a podstrčil mi kus chleba. Chce se také podívat do mého bytu. Ach, existují ještě dobří lidé, nesmíme se podat zoufalství!

(Tamtéž: 43) 
21. června: V noci jsem se probudila, už proto, že jsem se nemohla nadechnout. Lékař má za to, že mám zánět čelních nebo nosních dutin; protože nemám žádné bolesti, nevěřím mu; nemá žádné vyšetřovací přístroje. Pan Válek mi skutečně připravil horký čaj a tři housky. Dokonce obstaral doušek kmínového likéru a cigaretu; tu jsem musela, i když jsem už nemohla dýchat nosem, bezpodmínečně vykouřit.“

(Tamtéž: 58)

Mezi poznámkami o pomoci jasně převažují takové, které prozrazují vzájemnou sexuální přitažlivost. V případě ,jiných“ dívek autorka sice místo o pomoci hovoří o ,výhodách“, které získávají, a náklonnost vi̊či sobě bud’to desexualizuje (jak výše uvedeno) nebo ji rámuje rétorikou romantické lásky. Bud' jak bud', téma je celkem zřetelné:

1. záŕí: Dařilo se mi celkem dobře v těchto dnech. Četař [česky v něm. originále], jehož pokoj jsem uklízela, mi řekl, že v kredenci je bílý chléb a sardinky, at' sním, kolik chci. Nenechala jsem se dvakrát pobízet. Povolává mě jen $\mathrm{k}$ těm nejlehčím pracím, často mě vyzývá, abych si udělala přestávku, nabízí mi místo ve feudálních křeslech a pak se kouří. Rusy odsuzuje v každém ohledu a zvláště neschvaluje, že znásilňují ženy. Chová se vždy bezvadně. [...] Jednou nesměle přednesl přání, jestli bych ho políbila...

(Tamtéž: 122)

\section{4. Subverzivní síla heterosexuality}

V každodenním životě by se vzájemná sexuální přitažlivost mohla zdát samozřejmou, z hlediska sociologie je ale třeba zdưraznit, že genderové vztahy tvoří „vedlejší‘, zvláštní strukturu, která často kříží zájmy hlavních mocenských struktur. Hlavním kontextem narace M. Schellové je vztah mezi příslušníky vítězných a poražených národů, který má bezprostředně po ukončené válce neprrátelský charakter. Takovýto jasně definovaný vztah ale mezi sebou mohou udržovat jen soupeřící heterosexuální prŕíslušníci mužského pohlaví. ${ }^{23}$ V dvoupohlavních konstelacích muži a ženy přes všechny nepřátelské fronty směřují k sexuální směně, at' dobrovolné nebo vynucené, at' zištné či nezištné. Jinými slovy, sexualita je všudypřítomná a ovlivňuje akce a procesy, které s její existencí nepočítají.

Tam, kde muži mají moc a ženy mají jen tělo, spočívá násilí vůči ženám právě v tom, že se jim nedostává jiných ressourcí. Směňovat vlastní tělo znamená zbavovat se tělesné integrity, jejíž význam jsme již shora naznačili. Do této situace se v našem př́padě dostaly německé ženy v důsledku války, začaté a prohrané jejich muži. Ve vztahu k „cizím“ mužům z vítězného tábora, at' Čechům nebo Rusům, uplatňují „přírodni'“ komoditu, která se vymyká národnostnímu a jiným zařazením. Násilná situace proto neznamená, že jsou ženy odsouzeny jen ke statutu obětí. V deníku se mnohokráte objevilo, že ženy od mužských strážců získávaly mnoho výhod, které nemusely být vždy zaplaceny tělem. Podmínkou ale je heterosexualita a znalost implicitních norem „správného zacházení“ se ženami, kterého se podle autorky často zhošt’ovali i jinak „,barbarští “ Rusové. Sexualita se vůči mocenským strukturám projevuje jako subverzivní síla. 


\section{5. Ženy $v$ nové zemi}

\section{1. Sexualita jako zvratný bod akulturace žen}

Zvláštními podmínkami života žen v nové zemi se zabývá Oliva M. Espín(ová). Jako imigrovaná psycholožka hispánského původu se často setkávala se ženami, které zažívaly stres pro spor starých a nových vzorů sexuality. Mnohé z nich sice opustily patriarchální rád, nemohly se ale vyrovnat s vlastními internalizovanými až inkorporovanými představami o správném sexuálním chování. V přijetí nových svobod jim však nebrání jen vlastní představy, ale i role, která je jim vnucována jejich etnickou skupinou žijící v diaspoře. Espínová poukazuje na to, že imigrovaná skupina nemá své nové životni podmínky pod kontrolou nebo, což je totéž, nemůže nové životní podmínky, jakými jsou zpo̊sob obživy, bydlení, školství, oficiální jazyk atd., ovlivnit. Jako obranný mechanismus proto tradiční patriarchální rodiny, různým dílem otcové i matky, volí kontrolu směřovanou „dovnitř‘“, kontrolu své vlastní skupiny. Ta má zajišt'ovat osobní stabilitu členů tím, že zachovává kontinuitu tradice. Přes všechno, což už o významu genderu víme, je přece jen zarážející, že ona tradice se týká v prvé řadě vzorů pro mužské a ženské chování, jejich vztahu nadřizenosti a podř́zenosti, tak jak se projevují v kulturních vzorcích sexuality (1999: 13). Patriarchální vztahy ve „staré“ vlasti jsou v nové zemi muži (a po určité době i ženami samotnými) idealizovány, což má ženám zabránit v tom, aby se akulturovaly ve smyslu demokratičtějších vztahů mezi muži a ženami v západním světě. Ženy ovšem tyto nové vztahy vnímají, a když proti svým „tradičním“ mužům nerevoltují přímo, projevuje se jejich sympatie s poměry v nové zemi v tom, že signifikantně častěji odmítají myšlenku na návrat do vlasti (tamtéž: 24). Vyjednávání norem správného sexuálního chování se týká především mladistvých, kteří bojují s otcovskou i mateřskou autoritou o právo na schůzky s příslušníky druhého pohlaví, o právo dívek pohybovat se vně rodiny bez doprovodu, o právo volit si vlastního životního partnera (tamtéž: 25 a dále.). ${ }^{24}$ Zvláštním problémem, jak pro ženy samé, tak pro jejich prostředí, je pak akceptace lesbické sexuální orientace, která, jak výzkum Espínové zjevuje, byla i častým, mnohdy ještě neuvědomovaným, motivem k emigraci.

Z rozhovorů, které Espínová v Americe provedla a vyhodnotila, vybíráme tyto ukázky konfrontace starých a nových zkušeností. Marguerite z Rakouska vypráví o svém dětství:

Oblast, ze které pocházím, je velice, velice katolická... Snad je to kombinace tohoto katolictví a určitého typu zemědělské kultury, co zapříčinilo vytvoření velice rigidního postoje $\mathrm{k}$ sexualitě, obzvláště u žen. Tak např́íklad, tam kde jsem vyrostla, na statku, jsem nikdy neviděla nikoho nahého. Proto jsem velmi nesvobodná. A uvědomuji si rozdíl, jaký je mezi mnou a ženami z Německa. Muži v Rakousku, oni opravdu nevědí, jak se ženou zacházet, nejsou to dobří milenci.

(Tamtéž: 58)

Hilda z Německa zdůrazňuje, jakou jí chtěli mít rodiče a jak se změnila v Americe:

...pokud se týče mě samé, tak je to zakoušení tlaku daného snahou vyhovět představě rodičů. V podstatě, oni by mě i nyní rádi viděli vdanou a s dětmi. A stále jaksi „potaji““ doufají, že přestanu být lesba... Velice silně cítím, že bych byla někým jiným, kdybych zůstala v Německu, kde by na mě působily úplně jiné vlivy. Nebyla bych tak silná, tak sebevědomá.

(Tamtéž: 65) 
Korejka Jazmin se musí vyrovnávat s existencí rasistických sexuálních stereotypů:

Asijské ženy jsou cizími lidmi snadno považovány za „kurvy“, pokud jsou na veřejnosti spatřeny $\mathrm{s}$ bělochem. Děsí mě představa, jak jsem vnímána cizinci, když se na veřejnosti chovám něžně ke svému bělošskému příteli. Velmi dobře vím, že můj původ je jedním z důvodů, proč přitahuji některé bělochy. Je pro mě těžké uvěřit tomu, že rasový původ není nezbytnou součástí sexuality.

(Tamtéž: 70)

Výběr př́kladů završíme vyprávěním Loreny z Puerto Rica a Cindy z Taiwanu, které obzvlášt' plasticky odhalují přesah sexuality do akulturace. V jejich př́ípadě souvisí s jazykem:

Otevřená mohu být v angličtině, ale ne ve španělštině. Jakmile letadlo přistane v Portoriku, je to jako bych se „zavřela“ a lesbou se opět stanu, až když jsem zpátky v U.S. Trvalo mi to věčnost, než jsem v angličtině řekla některá slova. A je stále nemožné říci tato slova španělsky.

(Tamtéž: 78)

Cindy hovořila čínsky jen se svými rodiči, a to nikdy o sexualitě. Ani jeden z jejích sexuálních partnerů nebyl Číňan, takže neměla př́iležitost hovořit o intimních věcech v čínštině. Ukazuje se, že možnost a schopnost zřetelně artikulovat svou sexuální identitu a své intimní zážitky tvoří důležitý předpoklad veřejného sociálního statutu žen v rámci genderové struktury společnosti (tamtéž: 80).

Espínová svým empirickým výzkumem doložila tezi, že regulování sexuality je důležitou, neprávem přehlíženou součástí politických a sociálních, zvláště pak náboženských konstrukcí. Porušení sexuálních vzorců otřásá skrytým jádrem těchto konstrukcí, což se stává zřejmým právě při konfrontaci dvou kultur v imigračních zemích. Normování sexuality se opět projevuje jako důležitý genderový aspekt displacementu.

\section{2. Ženy vítězné}

Na závěr genderového pohledu na displacement, ve kterém převažovaly jeho negativní důsledky pro ženy, se zmíníme o ženách, které pozměnily svět. Pro nedostatek místa uvedeme jen zvláště výmluvnou, odvážnou a do značné míry samostatně zvolenou cestu Goldy Meir(ové), tak jak ji stručně popsala známá autorka Schwarz-Gardos(ová) (1979).

Dětství Goldy Meirové je poznamenáno všemi atributy, které miliony lidí přninutily k opuštění rodného místa. Ve své autobiografii vzpomíná na židovský pogrom v Kyjevu:

Otec zabednil okna i dveře, aby nás uchránil před rozvášněným davem. Pro mě a mnoho dalších Izraelců jsou nejranější vzpomínky spojené s masakry... Patřila jsem k těm relativně št’astným; unikli jsme se zdravou kůží. Ale miliony dalších později zahynuly během holocaustu... V Izraeli žije třistatisíc lidí, kteří přežili nacistickou katastrofu, kteří do zdejšího útočiště dorazili více mrtví než Živí... Z tragédie naší minulosti jsme se naučili, že mír je nejdůležitější věcí na světě.

(Schwarz-Gardos 1979: 22)

Golda Meirová nikdy nezapomněla, že se narodila jako dcera velmi chudého truhláře Mosche Mabowitze v Kyjevu. Často neměli nic k jídlu, malá Golda trpěla hladem. Rodina vysídlila do Ameriky. Matka bránila Goldě ve studiu, ze strachu, že by „zintelektualizovaná“ 
dcera nenašla manžela, což by pro rodinu znamenalo značnou katastrofu. Proti vůli své matky si Golda vybojovala vzdělání učitelky, a aby se vymanila z vlivu rodičů, odstěhovala se ke své sestře do Denveru. Tam pracovala v prádelně, kde také poznala svého pozdějšího manžela Morrise Meyersona, který měl velmi pozitivní vliv na její další intelektuální vývoj. Již tehdy se seznámila s budoucími politiky ještě neexistujícího státu Izrael - s Davidem Ben-Gurionem a Jizchakem Ben-Zwi (tamtéž: 22 a dále). Golda Meirová se již svým studiem a posléze svou celoživotní angažovaností ve věcech veřejných stala předchůdkyní boje o práva žen a př́kladem, který je hodný následování. Příznačné pro její cestu ale je, že se nikdy na tzv. ženskou otázku neomezovala, naopak ji chápala jako součást sociální politiky.

Po založení státu Izrael se Golda Meirová stala první vyslankyní v Moskvě, poté byla ministryní pro práci i ministryní zahraničních věcí, sekretářkou nejdůležitější strany země, strany „Práce“. Byla už ,jednou nohou“v důchodu, když se - více než sedmdesátiletá - po smrti Levy Eschkola stala ministerskou předsedkyní ve své vojensky obležené vlasti. Za své zvolení prý vděčí tomu, že o post „bratrovražedně“ bojovali dva mužští kandidáti: Mosche Dayan a Jigal Allon. Paní Meirová již ale velmi brzy dokázala své politické schopnosti úspěchy, které tu nemůžeme ani náznakem popsat. Na jednu stranu ji nazývali jediným mužem v kabinetu, na druhou stranu parafrázovali její politickou činnost jako působení v její „kuchyni“. Když se vracela z Ameriky s prŕíslibem velkorysé hospodářské pomoci Izraeli, objevila se karikatura Meirové s plným nákupním košem. Paní Meirová, matka dospělých dětí a babička několika vnoučat, se skutečně chovala jako „muž“: pracovala dvanáct hodin denně, vykouřila až šedesát cigaret a vypila nekonečný počet šálků kávy... Železná babička při tom byla stejnou měrou ,železnou“ jako „babičkou“. Ve své autobiografii podrobně líčí své dlouholeté výčitky svědomí a sebeobviňování z toho, že zdánlivě zanedbává muže a děti. Všechno ale svědčí o tom, že jí děti nic nevyčítaly. Se svými dospělými dětmi se radila, zvláště o svém úmyslu kandidovat na funkci ministerského předsedy (tamtéž: 23 a dále).

$\mathrm{Z}$ analytického sociologického pohledu je třeba vyzdvihnout onen androgynní moment, který se projevuje jak v autobiografii, tak ve veřejném označování Goldy Meirové jako pravého muže, parafrázování její politické činnosti div ne jako čarodějnické kuchyně. Veřejná politická činnost vyžaduje určité vlastnosti a schopnosti, a přestože jsou chápány jako mužské, musí jimi disponovat i žena. ${ }^{25}$ Zvolený prŕklad při tom není vůbec výjimečný - při dostatečné pozornosti bychom jistě objevili mnoho $\mathrm{knih}^{26}$ podobných autobiografii Halimy Alaiyan(ové), Palestinky, která z Izraele „utekla“ do Německé spolkové republiky. Alaiyanová podává svědectví o tom, jak se z muslimky zcela podrobené manželovi stala živitelka rodiny, rozvedená žena, lékařka a posléze autorka německé publikace (2003).

\section{Shrnutí}

Popsané genderové aspekty displacementu se nám odkrývaly postupně a neplánovitě. Pojednání se ale pouze nedoplňovalo dalšími obsahy, spíše jsme začali pronikat ke skrytým významům genderu. Začali jsme poukazem na tzv. „,reproduktivní funkci“ migrujících žen, která se netýkala výchovy dětí, ale služeb; at’ pro manžele či pro zákazníky prostitutek. Přirozená reprodukce lidského rodu, rození a výchova dětí, která se z hlediska biologické nutnosti jeví jako prvotní, se při podrobné analýze sociálních souvislostí posouvá na druhé místo, 
za reprodukci dospělých mužů samotných. Tzv. přirozená reprodukce slouží legitimizaci podřadného postavení žen. $Z$ ekonomické závislosti se odvíjí celková podř́zenost žen. Závislé ženy nemohou dosáhnout rovnocenného sociálního statusu, který by jim po právu náležel.

Při pojednávání násilných aspektů vymístování, se projevila rudimentárnější složka genderovaných vztahů - totiž okolnost nerovné vybavenosti ženských a mužských těl (ceteris paribus) fyzickou silou. Ta dodnes tvoří účinný prostředek udržování mužské nadvlády, a to jak ze strany soukromých, tak i veřejných, „hegemoniálních“ mužů. Mocensky manipulované násili na ženských tělech prozradilo, že i znásilňování žen má jinou než „přirozenou“ sexuální motivaci: jeho smyslem je podrobit si „tělo“ protivníkova národa, etnika atd. Ženské tělo má nejen konkrétní reproduktivní funkci v mužských službách, ale i symbolickou funkci v rámci reprodukce skupinových identit.

Tím se ovšem genderové vztahy nevyčerpávají. Analýza některých strukturně násilných situací vymístění totiž odhalila latentní přítomnost nemanipulované sexuální přitažlivosti, která pak intervenuje do mocenských struktur. Sexuální vztahy se bez ohledu na zákazy vytváŕejí prakticky ve všech situacích a mají tak schopnost narušovat mocenské úmysly. Další skutečnost, že lidé v nouzi svá těla, popřípadě své sexuální služby, také směňují, je s odhlédnutím od morální stránky prostě nutno vzít na vědomí.

Od ztráty lidské důstojnosti v migraci, přes význam fyzického násilí a možnosti symbolického zneužívání těla jsme se nakonec vrátili k důstojnosti, kterou mohou vymístěné ženy získat. A právě v tomto bodě se genderové aspekty vymístění zvrátily v pohled na gender samý: otázkou již není, jak obohatit výzkum vymístění, ale jak tento výzkum obohacuje naši znalost genderu. Zdá se totiž, že se lidská důstojnost žen během migrace zvyšovala tou měrou, s jakou byly ochotny přestupovat úzké hranice svého genderu. Nejen sexuální chování, které tvoří skryté jádro genderových vztahů, ale genderové role ve své celistvosti, prochází v imigrantské zemi značnou proměnou, která pro mnohé ženy znamená výrazné zlepšení jejich sociálního statutu a životních šancí.

\section{Poznámky}

Srov. Bammer (1994); dále Hoerder (1993).

2 Hoerder (1993) mimo jiné odkazuje na systémový př́stup k migraci, který zahrnuje právně-politické aspekty státních občanství, ekonomickou situaci, demografické aspekty, pracovní trh a socio-kulturní aspekty v zemích migračního pohybu (srov. Jackson/Moch (1989).

3 Př́činou nedostatečných úrod mohou být i př́rodní katastrofy (srov. Bammer 1994: xi)

4 Srovnej Roller (1994).

$5 \quad$ Přesné určení doby v textu chybí, podle všeho se př́pad odehrál v pưli 19. století.

6 Za bohatého platil $\mathrm{v}$ této vesnici ten, kdo si mohl do polévky zavařovat rýži nebo dokonce někdy i maso (Hoerder 1993: 25).

7 Dělo se tak ,k jejímu dobru“.

8 Evropské nevěsty se do Ameriky dohazovaly prostřednictvím dopisů - jednalo se o tzv. mail-order-brides. Z Japonska se sjednávaly prostřednictvím obrázků - tzv. picture brides (Hoerder 1993: 26). 
Srov. Staudacher (1996).

10 Situaci ve štetlech autor předcházejícího pojednání označil jako důsledek násilného vymístění Židů ze zemědělských usedlostí v Carském Rusku v letech 1795 a 1835 (Pale of Settlement, Hoerder 1993: 8).

11 V Hamburku jakožto zámořském př́istavu zaznamenali, že 90 \% prostitutek pochází z Rakousko-Uherské monarchie (Staudacher 1996: 14).

12 V roce 1885 lvovská policie registrovala 395 takovýchto ,agentů“ (Staudacher 1996: 14).

13 Srov. La Strada Česká republika (1997).

14 Rozdíl mezi mužskou a ženskou tělesnou pracovní silou spočívá dále v tom, že zatímco mužské tělo zůstává při práci intaktní, je ženské tělo při výkonu služby penetrováno. Penetrace těla je v moderní společnosti natolik významná, že je schopna „udělat“ z penetrovaného muže „ženu“ (Pateman 1988). Jak ukazují výzkumy vězeňských a jiných kultur, penetrace má ,genderotvorný“ význam (srov. Smaus 1991; Nedbálková 2003). Při mužské prostituci je tomu tak, že pokud je prodávající muž penetrován, ztrácí svoji „mužnost“. Když nabízí heterosexuální genitální sex, pak penetrací platící ženy opět jen potvrzuje její nižší genderový status, o to „horší“, že si za sex musí platit. Ze symbolismu penetrace se jen těžko vystupuje, i když v masmédiích v poslední době převažují ukázky sexu, při kterém je žena „nahoře“. Tato poloha analogicky naznačuje, že pronikání dvou těl lze chápat i jako aktivní uchopování ze strany ženy.

15 Vědomí o potenciálním ohrožení násilím ze strany mužů a následném připsaní zodpovědnosti obětem - ženám -, ovlivňuje životní trajektorie žen i v „civilizovaných“ zemích. Hrozba násilí tak tvoří ultima ratio patriarchátu. Srov. Smaus 1986.

16 Tamilové od znásilněných žen očekávají, že spáchají sebevraždu, zvláště pokud otěhotněly (Laubenthal 1999: 32, podle Hofmann 1988).

17 Laubenthal 1999: 41, podle Schaaf/Essinger/Preuss 1988: 313.

18 Laubenthal 1999: 45, podle Amnesty International 1992: 7.

19 U etnika totiž na rozdíl od jiných autorů nezdůrazňuje jeho kulturní aspekt, ale považuje ho hlavně za výsledek mocenských bojů.

20 Autorka analyzuje i zpravodajství o znásilněných mužích, zvláště muslimech ze strany Srbů. $\mathrm{V}$ tomto případě se symbolicky zdůrazňuje, že muslimové (v bývalé Jugoslavii) jsou vlastně kastráti, homosexuálové, slaboši apod., vlastně podřízené „ženy“, a proto nemají nárok na vlastní prokreativní udržování etnika (Zarkov 1999: 266 a dále)

21 Jako politicky nekorektní dnešní čtenář pocit’uje i zdůrazňovaní, že někdo z vítězné strany je Židem. Je zcela jasné, že autorka reprodukuje nacionálně-socialistickou stigmatizaci Židů, a to i tam, kde je chválí. Vyvstává otázka, jak budou naši potomci číst a interpretovat současné časté pojmenovávání - „vypichování“, stigmatizování - Romů, stejně tak jako znovuzavádění nevědeckého výrazu „rasa“.

22 Př́nosná by například byla analýza sňatkových inzerátů ruských novin vycházejících v Německu. Za výhodného partnera se považuje Rus, který již získal německé občanství nebo oprávnění k trvalému pobytu spolu s př́ijmem sociální podpory.

23 Proto také není homosexualita stíhána nikde tak přísně jako v armádách. Ve styku dozoroců a internovaných mužů se ovšem také uplatňují socio-psychické mechanismy komunikace, které vedou ke vzniku soucitu, sympatií a potřeby pomoci.

24 Zvláštní zdrojem sporů během akulturace tvoří pravidla správného oblékaní pro muže a ženy (Espín 1999: 125 a dále; cituje Schreier 1994). Oblečení symbolizuje genderové vztahy a v právnickém boji fundamentalistů o nošení šátků jde nejen o zachování vnitroetnické nadvlády nad jejich ženami, ale hlavně o vyjmutí celého etnika ze svrchovanosti imigrantské země. 
25 Změna genderových rolí samozrejmě spočívá v novém nastavení „genderovaných vlastnosti““. Vznikají nové patch-work či blended identities. Srovnej Smaus 1998; Šmausová 2002; Smaus 2003.

26 Srov. např́klad i Herzberg, Igersky 2000: 118 a dále.

\section{Literatura}

Alayian, H. 2003. Vertreibung aus dem Paradies. München: Ullstein Heyne List GmbH.

Bammer, A. 1994. „Introduction.“ In Displacements. Bloomington, Indianapolis: Indiana University Press.

Espín, O. M. 1999. Women Crossing Broundaries: A Psychology of Immigration and Trasformation of Sexuality. New York, London: Routledge.

Hoerder, D. 1993. People on the Move. Migration, Acculturation, and Ethnic Interaction in Europe and North America. Oxford: Providence.

Herzberg, H., Igersky, S. 2000. „Ehe im fremden Land. Eine Wendezeit für Migrantinnen?“ In B. Dausien, M. Calloni, M. Friese (eds.) Migrationsgeschichten von Frauen. Beiträge und Perspektiven aus der Biographieforschung. Bremen: Universität, s. 118-136.

Hoffmann, T. 1988. „Tamilinnen sind doppelte Opfer.“ In K. Moussa-Karlen, E. Bauer (eds.) Wenn Frauen flüchten. Bern, Zürich.

Jackson, J. H., Moch, L. P. 1989. „Migration and the Social History of Modern Europe.“ Historical Methods 22: 27-36.

Krell, G., Wölte, S. 1995. Gewalt gegen Frauen und die Menschenrechte. Frankfurt am Main.

La Strada Česká republika 1997. Traffic in Women in Postcommunist Countries of Central and Eastern Europe. Praha.

Laubenthal, B. 1999. Vergewaltigung von Frauen als Asylgrund. Frankfurt am Main: Campus.

Lévi-Strauss, C. 2000. Die elementaren Strukturen der Verwandschaft. Frankfurt am Main: Suhrkamp.

Nedbálková, K. 2003. „Má vězení střední rod? Aneb Maskulinita a femininita ve vězeňských subkulturách.“ Sociologický časopis, 39: 469-486.

Roller, K. 1994. Frauenmigration und Ausländerpolitik im Deutschen Kaiserreich. Polnische Arbeitsmigrantinnen in Preußen. Berlin: Dieter Bertz Verlag.

Schaaf, P., Schuckar, M. 1995. „Fluchtgründe für Frauen in der Einschätzung von asylrechtlichen Entscheidungsinstanzen und RechtsanwältInnen: Ergebnisse einer empirischen Untersuchung." In Frauen auf der Flucht, Bd. 2: Weibliche Flüchtlinge im deutschen Exil., Berlin, s. 133-174.

Schell, M. 1957. Ein Tagebuch aus Prag, 1945-46. Aufzeichnungen von Margarete Schell. Bez udání místa: Herbert M. Nuhr, Kassel-Wilh.

Schreier, B. A. 1994. Becoming American Women: Clothing and the Jewish Immigrant Experience, 1880-1920. Chicago: Chicago Historical Society.

Schwarz-Gardos, A. 1979. Frauen in Israel. Die Emazipation hat viele Gesichter. Ein Bericht in Lebensläufen. Freiburg i. B.: Herder.

Smaus, G. 1991. „Reproduktion der Frauenrolle im Frauengefängnis, mit Bereichsbibliographie." Streit, Heft 1: 23-33. 
Smaus, G. 1994. „Physische Gewalt als ultima ratio des Patriarchats.“ Kriminologisches Journal, 2: 82-104.

Smaus, G. 1998. „Kulturelle Androgynität am Beispiel der eingeschlechtlichenInstitution des Gefängnisses.“ In Sofies Fächer. SOFIE, Saarländische Schriftenreihe zur Frauenforschung, Band 9, s. 131-153.

Šmausová, G. 2002. „Proti tvrdošíjné představě o ontické povaze gender a pohlaví.“ Sociální studia, 7: 15-27.

Smaus, G. 2003. „,Ich bin ich“ - Feminismus als Avantgarde der Bewegung für Menschenrechte." In R. de Giorgi (ed.) Il diritto e la differenza, Scritti in onore di Alessandro Baratta . Lecce: 1'Editore Pensa MultiMedia, s. 601-619.

Staudacher, A. L. 1996. „Historical Account about Trade in Women and Girls in Eastern Europe.“ In Heinrich Böll Foundation (ed.) Conference: Sexwork, Sextourism and Trafficking in Woman: A New Reality in Eastern Europe? Prague, s. 12-17.

Zarkov, D. 1999 From ,Media War' to ,Ethnic War'. The Female Body and the Production of Ethnicity in Former Yougoslavia. Centre for Women's Studies, University of Nijmegen.

\section{Autorka}

Prof. Dr. phil. Gerlinda Šmausová, Priv.-Doz., socioložka, působí od roku 2001 na Fakultě sociálních studií Masarykovy univerzity v Brně a na Filozofické fakultě Univerzity Palackého v Olomouci. Současným předmětem jejího výzkumu jsou aspekty genderové diferenciace společnosti. Kontaktní e-mail: smausova@fss.muni.cz 